\title{
Answer to "Reevaluation of the conclusion that IRES-activity reported within the 5 ' leader of the TIF4631 gene is due to promoter activity"
}

MICHAEL ALTMANN, HANS TRACHSEL, MARTIN VONLANTHEN, AND VALÉRIE VERGÉ

Institute for Biochemistry and Molecular Biology, University of Berne, $\mathrm{CH}-3012$ Bern, Switzerland

\begin{abstract}
The accuracy of the data we reported in an RNA Letter to the Editor earlier this year on the promoter activity within the $5^{\prime}$ leader of the TIF4631 gene is questioned by V.P. Mauro and others in this issue. We reply here that we see no inaccuracy in our data.
\end{abstract}

A crucial experiment was omitted in the original paper by Mauro and coworkers (Zhou et al. 2001, Figs. 4, 5): determining the activity of the second open reading frame (ORF) from their bicistronic constructs expressed in yeast cells kept under repressing conditions (glucose).

This is what we have done using their bicistronic constructs in our recent paper (Vergé et al. 2004, Fig. 2). This control experiment shows that expression levels of the second ORF are similar under repressing conditions (glucose) and under derepressing conditions (galactose). This is a clear indication for an internal promoter activity.

We have confirmed the presence of a promoter by creating deletions in this region of the TIF4631 gene and showed that the deletion of most of this region still allowed cells to produce similar levels of Tif4631 protein like wildtype cells and that the promoter activity is located in the region 112-36 (Vergé et al. 2004, Figs. 4, 5). We have stated

Reprint requests to: Michael Altmann, Institute for Biochemistry and Molecular Biology, University of Berne, Bühlstrasse 28, CH-3012 Bern, Switzerland; e-mail: michael.altmann@mci.unibe.ch; fax: 0041-31-63137-37.

Article and publication are at http://www.rnajournal.org/cgi/doi/ 10.1261/rna.7410604. that all our deletion constructs have been sequenced to exclude mutations and/or DNA rearrangements. We know that TIF4631 is expressed at low levels in wild-type cells and that this mRNA was easily missed in the Northern blotting experiments presented in their original paper.

Mauro et al. (2004) argue in their reevaluation: "Even if these cells were rescued by what appears to be a weak promoter, this result is not informative regarding the activity or location of the native promoter." We show that this promoter activity explains the expression of the second ORF obtained with their bicistronic constructs.

\section{REFERENCES}

Mauro, V.P., Edelman, G.M., and Zhou W. 2004. Reevaluation of the conclusion that IRES-activity reported within the $5^{\prime}$ leader of the TIF4631 gene is due to promoter activity. RNA (this issue).

Vergé, V., Vonlanthen, M., Masson, J.-M., Trachsel, H., and Altmann, M. 2004. Localization of a promoter in the putative internal ribosome entry site of the Saccharomyces cerevisiae TIF4631 gene. RNA 10: $277-286$.

Zhou, W., Edelman, G.M., and Mauro, V.P. 2001. Transcript leader regions of two Saccharomyces cerevisiae mRNAs contain internal ribosome entry sites that function in living cells. Proc. Natl. Acad. Sci. 98: 1531-1536. 

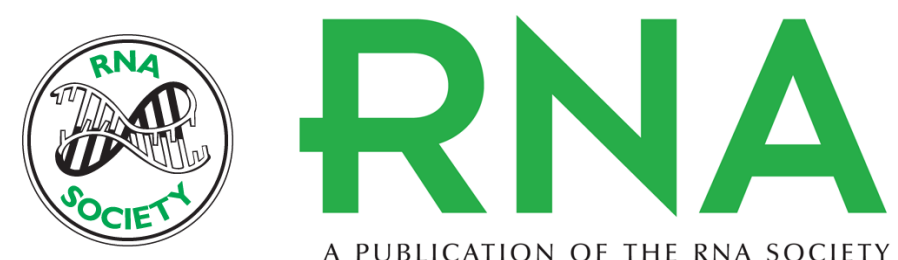

A PUBLICATION OF THE RNA SOCIETY

\section{Answer to "Reevaluation of the conclusion that IRES-activity reported within the 5 ' leader of the TIF4631 gene is due to promoter activity"}

MICHAEL ALTMANN, HANS TRACHSEL, MARTIN VONLANTHEN, et al.

RNA 2004 10: 898

\section{Related Content}

Reevaluation of the conclusion that IRES-activity reported within the $\mathbf{5 2}$ leader of the TIF4631 gene is due to promoter activity

VINCENT P. MAURO, GERALD M. EDELMAN and WEI ZHOU

RNA June , 2004 10: 895-897

References This article cites 2 articles, 2 of which can be accessed free at:

http://rnajournal.cshlp.org/content/10/6/898.full.html\#ref-list-1

Articles cited in:

http://rnajournal.cshlp.org/content/10/6/898.full.html\#related-urls

\section{License}

Email Alerting

Receive free email alerts when new articles cite this article - sign up in the box at the Service top right corner of the article or click here.

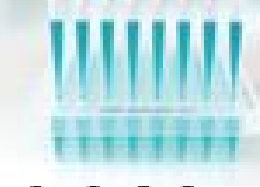

Providing Precise Solutions for your research. 